\title{
Analysis of noise on construction sites of high-rise buildings
}

\author{
Béda Barkokébas Jr.', Bianca M. Vasconcelos, Eliane Maria G. Lago and Aline Fabiana P Alcoforador \\ ${ }^{a}$ Laboratório de Segurança e Higiene do Trabalho, Universidade de Pernambuco, biancalsht@poli.br, \\ Recife/PE, Brasil
}

\begin{abstract}
In the civil construction industry sector, it has been observed that the increasing use of machines has made tasks noisier and consequently caused hearing loss and had other adverse effects on workers. The objective of this study was to identify and assess the physical risks of noise present in activities undertaken in a construction company in order to propose control measures which will contribute to the management of health and safety within the company's organization. The methodology applied was based on verifying the characteristics of exposure to noise on construction sites, from an observation of sources which generated noise and making measurements of sound pressure levels emitted by these sources. The data was then analyzed and compared with the recommended performance levels established in control measures. As a result, it was found that some machines and equipment used in civil construction often generate noise above the acceptable levels and as such, in these cases, various control measures have been proposed. It is believed that the use of management techniques is the most effective way to assess risk and to implement the preventive and corrective actions proposed, and allows for the analysis of sound pressure levels on an ongoing basis.
\end{abstract}

Keywords: Construction, Health and Safety at Work, Noise.

\footnotetext{
${ }^{*}$ Corresponding author. E-mail: editorial@iospress.nl. Check if the checkbox in menu Tools/Options/Compatibility/Lay out footnotes like Word 6.x/95/97 is selected if you make a footnote for the corresponding author.
} 


\section{Introduction}

The activity of work represents, primarily, an important means of achieving personal satisfaction, and only then a source of livelihood for the individual and his family. It is through work that man expresses his creativity, formulates thoughts, develops new habits, new social relationships and new knowledge, thereby contributing to meeting the needs and the evolution of society to which he belongs. However, every day, the environment, tools, machines, and postures, as well as other variables present in the workplace, expose the human being to situations that damage (physical and mental) his health.

Therefore, there is a real need to undertake preventive and corrective measures for the elimination or mitigation of these possibilities for damage. That is to say, occupational hazards (physical, chemical, biological, ergonomic and accidental). Among the environmental agents that are characterized as occupational hazards, noise stands out by being present in almost all human activities (at home, at work and even leisure time) and also in the damage and nuisance it causes to humans.

In relation to the construction industry, what can be observed is that the increasing use of ever faster machines has made tasks noisier and consequently caused hearing loss and other adverse effects in increasing numbers of workers. However, these damages are not assessed properly by companies and government institutions (2).

Therefore, this study is justified by the need to perform an effective assessment of the noise generated in the civil construction environment, taking into account the particular characteristics of the sector and using management techniques in order to contribute to the formation of a healthy and productive environment.

The study aims to identify and assess the physical risk noise presents in the activities of a construction company in order to propose control measures in such a way as to contribute to the management of health and safety within the organizational environment.

\section{Environmental Risks}

The Regulation NR 9 - Program of Prevention of Environmental Risks (3) - defines environmental risks as physical, chemical and biological agents present in work environments that, due to their na- ture, concentration or intensity and exposure time, are capable of causing damage to workers' health.

Physical agents are defined as the various forms of energy that workers can be exposed to, such as noise, vibration, abnormal pressures, more extreme temperatures, ionizing radiation, non-ionizing radiation, as well as infrasound and ultrasound .

Chemical agents are already classified as substances, compounds or materials that may enter the body through the respiratory route in the form of dust, fumes, mists, gases or vapors, or that by the very nature of exposure, may have contact or be absorbed into the body through the skin or swallowed. Finally, we consider biological agents, legally, as bacteria, fungi, bacilli, parasites, protozoa and viruses, amongst others (3).

Some authors consider the risks only as physical, chemical and biological, focusing their attention on the analysis of measurable variables that cannot, somehow, be subjective (1).

They also consider environmental risks beyond those already mentioned, and the risks of accidents or mechanical and ergonomic risks, in order to maximize the scope of analysis and, consequently, the search for protective measures.

Thus, the mechanical hazards or accidents, are those resulting from the presence of materials as opportunities for damage: a result of overheated friction between different parts, moving parts, sharp edges, unprotected motors, the presence of uneven surfaces, movement of cargo in transit, exposed wiring, etc (1).

Ergonomic risks, in turn, result from conditions which are contrary to the techniques of ergonomics, which require workplaces to adapt to humans, and thus provide physical and psychological welfare. Ergonomic risks can be defined as: physical exertion, heavy lifting, poor posture, tight control of productivity, stress, working at night, long working hours, monotony and repetitiveness and the imposition of intense routines, amongst others (1).

\subsection{Noise}

The sound is any set of vibrations or mechanical waves that can be heard. For the vibration to be heard, the sound frequency (number of oscillations per time unit) needs to be between 16 and $20,000 \mathrm{~Hz}$, when the pressure variation caused by the vibration reaches the threshold of audibility, which is $2 \times 10-5 \mathrm{~N}$ / $\mathrm{m} 2$ or $0.00002 \mathrm{~N} / \mathrm{m} 2$ (4).

When this sound is subjectively interpreted as unpleasant and undesirable, it is called noise. From the 
point of view of occupational hygiene, noise vibration is the physical phenomenon that is characterized by a variation of indefinite pressures on the frequency. That is to say, for a given frequency to exist, at random through time, there need to be different variations of pressure (4).

The Regulation ISO 2204 (1979), Acoustics Guide to the measurement of airborne acoustical noise and evaluation of ITS effects on human beings - present one of the most used noise rating classifications - classifies noise in relation to time (2):

- Continuous: noise whose variation in level is negligible $( \pm 3 \mathrm{~dB})$ during the period of observation;

- Not continuous: noise levels vary significantly during the period of observation;

- Fluctuating: noise level showing continuous variation of an appreciable level during the observation period;

- Intermittent: noise whose level falls rapidly to the level of the environment, at various times during the observation period; besides this, the duration in which the level retains a constant value which is different to the environmental value, is the same as or for more than one second;

\section{Control Measures}

The technical control measures can be in three distinct ways: at the source, the trajectory and in man. He notes that the measures at the source and the trajectory should be a priority when technically feasible (4).

\subsection{Control at source or trajectory}

The control at source is the recommended method when it is technically feasible. Its use is more appropriate during the planning phase, since at this stage you can choose those that produce lower noise levels and organize the physical layout of the workplace (4). Among the measures for controlling the source, Saliba (2008) highlights:

- Replacement of equipment with more silent equipment;

- Balancing and calibration of moving parts;

- Reliable lubrication of bearings, nuts and bolts, amongst others;

- Reduction of impacts where possible;

- Changing processes;
- Schedule operations so as to avoid the simultaneous operation of a large number of machines;

- Application of material that enables the diminishing of vibrations;

- Adjustment of motors;

- Maintenance of fixed structures, and thereby avoiding vibration;

- Replacement of metal gears with other plastic or Celeron processors;

- Reduced speed of escaping fluids;

- Reducing the speed of the machines;

- Installation of mufflers in the exhaust;

- absorption of impact by means of rubber linings in the structures and,

- Reducing the height of the drop of material into receivers.

\subsection{Control in the middle or trajectory}

If it is not possible to control at source, you should check the possible measures taken to control noise in the middle or trajectory. In trajectory control the sound is already generated so in this case the purpose is to prevent the spreading of noise or trapping a maximum of the lost energy through absorption(4). Thus, trajectory control can be achieved as follows:

- By absorption of sound through the acoustic treatment of surfaces. That is, coating the area with sound absorbent material in order to prevent possible reflections and,

- Using insulation in order to prevent transmission to another environment, starting from the use of materials that have high levels of noise reduction or loss of transmission. In this case, the isolation can be the source, building a barrier that separates the cause of the noise from its surroundings, or the receiver, separating the cause from the individual exposed to the noise.

\subsection{Control in the man}

As a last resort, if you cannot control noise at the source and the trajectory, one must adopt measures to control the worker, in order to complement the above measures, or when they are not sufficient to correct the problem (4). As measures of control in man, highlights:

- Limiting exposure time: In order to reduce the time that the worker is exposed to noise levels above the limits of tolerance, taking care that the maximum value for ex- 
posure to two or more different levels of noise does not exceed 1 (one); and

- Personal Protective Equipment (PPE) - ear protectors:

Hearing protection equipment is placed on the ear of the worker for individual protection, used whenever it is not possible to control noise to satisfactory levels. The choice of hearing protection is essential and, therefore, the advantages and disadvantages of each type must be noted and protective factors considered, amongst others

\section{Effects of noise on the body}

Noise is a risk factor present in various human activities, existing in the daily life of the community, at home and in most work processes (5).

Long periods of exposure to high noise levels usually causes damage to the human ear. Amongst the damage to hearing that exposure to excessive levels of noise can cause, Gabas (5) cites acoustic trauma, auditory temporary threshold shift (or Temporary Threshold shift - TTS) and Noise-Induced Hearing Loss (NIHL).

Acoustic Trauma occurs when a person is exposed to very high noise levels, causing sudden hearing loss.

The auditory temporary threshold shift, in turn, consists of a temporary hearing loss caused by exposure to high levels of noise for a short period of time. It is characterized, therefore, by a temporary change in hearing threshold. However, it returns to its original level after a rest in the noise. If noise exposure is repeated before the full recovery, temporary hearing loss can become permanent.

Finally, Noise-Induced Hearing Loss (NIHL), also known as occupational deafness, occurs because of prolonged exposure to high levels of noise, resulting in permanent hearing loss.

Hearing loss or diminution of auditory sharpness is the most immediate consequence caused by excessive exposure to noise. Its inception and degree depend on the level of pressure, duration of exposure, the noise characteristics and individual susceptibility (5).

However, the effects of noise are not limited to effects on hearing. Exposure to excess noise can harm or provoke psychological, physiological and even pathological damage. For example, acceleration of the pulse and increased blood pressure can cause anxiety, disruption of communication, irritability, and loss of income, amongst others (5).

Therefore, we can observe that noise, as well as other environmental agents, should be recognized, evaluated and controlled, so as to combat poor workplace conditions which can cause damage to workers' health and also increase the rates of accidents.

\section{Methodology}

Initially, we undertook bibliographical research on books, thesis, rules and regulatory laws, articles published in annuals and electronic networks in order to examine recent studies and historically important references on the topic under study. Then, seven visits were made to vertical construction building sites in the metropolitan region of Recife, in order to check the conditions of exposure to noise existing in the sites visited. This verification involved the identification of sources of noise, measurements of sound pressure levels in industrial environments evaluated for a period of four hours, and the quantitative assessment of exposure.

The criterion for the selection of sources of noise to be studied were based on the observation of the functions or activities of workers who frequently use machines and equipment and the noise they emit. As such, the levels of noise in the machinery and equipment analyzed are as follows:

- mixer - is a piece of equipment used for the preparation of concrete and varieties of mortar, using a mixture of cement, aggregates and water, in due proportion and texture, according to the type of work;

- circular bench saw - is an electric machine for cutting, used mainly on construction sites for cutting wood into different forms, boxes, roof structures and other secondary services;

To carry out assessments of noise in this study, we used three dosimeters; Quest Technologies Q-300 models, Q-400 and The Edge Eg4, portable, type 2. These were integrators and properly calibrated sound level. In the above configuration of equipment for measuring noise continuous or intermittent, if adopted the parameters specified in Norm NR 15, Annex I, the Ministry of Labor and Employment (6) and the Occupational Health Standard NHO 01 (7).

The data obtained from the measurement techniques were put in visual form using the Suit Quest ProfessionaI - QSP II, the computer program from 
Quest Technologies, which also made it possible to report on the measurements taken. Subsequently, these results were analyzed by taking into account the criteria for judging Regulation NR 15, of the Ministry of Labor and Employment (6) and the summary table of the Standard Occupational Hygiene NHO 01 (7).

Finally, after analyzing the data, proposals for actions of preventive and control measures for cases of machinery and equipment that generate sound pressure levels above the acceptable were studied. This takes into consideration that the use of management techniques is the most efficient way to undertake the assessment of the physical risks of noise, to implement the proposed corrective and preventive actions and to continually monitor the levels of noise in the workplace.

\section{Analysis and discussion of the results}

The results of the surveys in question are presented, based on the main sources of noise, and chosen according to set criteria. The average sound pressure levels emitted, as well as the doses of noise exposure to workers are represented in the form of tables. This is followed by a description of the causes of noise generated and then some specific measures of control and prevention are proposed.

To facilitate understanding, the seven construction sites analyzed in this study, by the hour, are called "a", "b", "c", "d" "e", "f" and "g ".

\subsection{Mixer}

\subsubsection{Measurement}

Table 1 shows that the emission of the Equivalent Sound Pressure level was verified as higher in the mixer on site "g", with $89.9 \mathrm{~dB}(\mathrm{~A})$, according to the parameters of NR 15, and $955 \mathrm{~dB}(\mathrm{~A})$, and with NHO 01. In addition to the level of noise, the highest value found was $196.4 \%$, according to the analytical parameters specified in NR, and $15 \%$ of 1124.3 , according to NHO 01. Therefore, corrective measures should be adopted immediately. This is also the case for a mixer on site "a" and mixers on site "d" and "e", since they had noise level emissions of 83.2, $87.7 \mathrm{~dB}$ and $88.5 \mathrm{~dB}$, respectively. In the case of mixer 2 , on site "a" and site "f", operators are exposed to levels of noise above the accepted level according to the more rigorous criterion of $01 \mathrm{NHO}$.
This therefore justifies the need for adopting preventive measures. Finally, using the technical considerations and the recommendations of FUNDACENTRO as a basis, and in respect to the normal daily emission or exposure level in the assessed environment, only the operator of the mixer on site "b" works to acceptable noise dosages. That is to say, below $50 \%$, and a Level of Exposure at $82 \mathrm{~dB}$. In this case, the action which would be recommended is to maintain existing conditions. It is also worth mentioning that despite the fact that the operators of the mixer on site "a" and of the mixers on sites "d" and "e" find themselves exposed to noise levels above the exposure limit, according to 01 criteria of the $\mathrm{NHO}$, this does not signify an unhealthy environment since the average exposure level is below the tolerance limit set out in NR 15, which is $85 \mathrm{~dB}(\mathrm{~A})$.

However, the same cannot be said of the equipment operator on site " $g$ ", since the measurement has shown a value of $89.9 \mathrm{~dB}$. Therefore, this worker is subject to additional health hazards. The risks of the mixers evaluated were classified as light and medium risk.

\subsubsection{Causes of noise}

Noise generation in this type of equipment depends on how the equipment is installed, the power of the machine, the volume capacity, charge level, the material being processed, and the maintenance of its parts, amongst other things. The noise is emitted by the motor / gearbox and the impact of the machine with the body or wall of the mixing vat. 
Table 1

Measurement of the noise level of mixers

\begin{tabular}{|c|c|c|c|c|c|}
\hline Equip amento & Norma & $\begin{array}{l}\text { Dose } \\
(\%)\end{array}$ & $\begin{array}{c}\text { Nivel de Pressão } \\
\text { Sonor a E quivalente } \\
\text { dB (A) }\end{array}$ & $\begin{array}{l}\text { Consider ação } \\
\text { Técnica }\end{array}$ & $\begin{array}{c}\text { Classificação do } \\
\text { risco }\end{array}$ \\
\hline \multirow[t]{2}{*}{$\begin{array}{l}\text { Betoneira } 1 \text { da } \\
\text { Obra "a" }\end{array}$} & NR -15 & 79 & 83,2 & $\begin{array}{c}\text { Acima do nível } \\
\text { de ação }\end{array}$ & Riscoleve \\
\hline & $\mathrm{NHO}-01$ & 140 & 86,4 & $\begin{array}{l}\text { Acima do limite } \\
\text { de exposição }\end{array}$ & Risco médio \\
\hline \multirow{2}{*}{$\begin{array}{l}\text { Betoneira } 2 \text { da } \\
\text { Obra "a" }\end{array}$} & NR -15 & 45 & 79,1 & Aceitável & Desconforto \\
\hline & $\mathrm{NHO}-01$ & 71 & 83,5 & $\begin{array}{c}\text { Acima do nivel } \\
\text { de ação }\end{array}$ & Riscoleve \\
\hline \multirow{2}{*}{$\begin{array}{l}\text { Betoneir a da } \\
\text { Obra "b" }\end{array}$} & NR -15 & 46 & 79,3 & Aceitável & Desconforto \\
\hline & $\mathrm{NHO}-01$ & 41 & 81,1 & Aceitável & Riscoleve \\
\hline \multirow[t]{2}{*}{$\begin{array}{l}\text { Betoneir a da } \\
\text { Obra "d" }\end{array}$} & NR -15 & 82,5 & 83,6 & $\begin{array}{c}\text { Acima do nível } \\
\text { de ação }\end{array}$ & Riscoleve \\
\hline & $\mathrm{NHO}-01$ & 190,1 & 87,7 & $\begin{array}{l}\text { Acima do limite } \\
\text { de exposição }\end{array}$ & Risco médio \\
\hline \multirow[t]{2}{*}{$\begin{array}{l}\text { Betoneira da } \\
\text { Obra "e" }\end{array}$} & NR -15 & 92,6 & 84,4 & $\begin{array}{l}\text { Região de } \\
\text { Incerteza }\end{array}$ & Riscoleve \\
\hline & $\mathrm{NHO}-01$ & 225,7 & 88,5 & $\begin{array}{l}\text { Acima do limite } \\
\text { de exposição }\end{array}$ & Risco médio \\
\hline \multirow{2}{*}{$\begin{array}{l}\text { Betoneira da } \\
\text { Obra "f" }\end{array}$} & NR -15 & 24,1 & 79,7 & Aceitável & Desconforto \\
\hline & $\mathrm{NHO}-01$ & 43,2 & 84,3 & $\begin{array}{l}\text { Região de } \\
\text { Incerteza }\end{array}$ & Riscoleve \\
\hline \multirow[t]{2}{*}{$\begin{array}{l}\text { Betoneira da } \\
\text { Obra "g" }\end{array}$} & NR -15 & 196,4 & 89,9 & $\begin{array}{l}\text { Acima do limite } \\
\text { de exposição }\end{array}$ & Risco médio \\
\hline & $\mathrm{NHO}-01$ & 1124,3 & 95,5 & $\begin{array}{l}\text { Acima do limite } \\
\text { de exposição }\end{array}$ & Risco médio \\
\hline
\end{tabular}

The mixers that were evaluated consisted of a loader, mixing tub and electric motor. During the measurements, the mixed material was composed of sand, cement and water, which resulted in lower levels of noise.

The figures 1 and 2 relate to mixers 1 and 2 on site "a", which, when compared with the mixers on site "b", illustrated in figure 3, can be considered old and poorly maintained. It is noteworthy that although the mixers are working with lightweight material, it was observed that measurements of noise in mixers 1 and 2 on site "a ', resulted in exposures to levels of noise above the permitted $50 \%$, according to the criterion 01 of the NHO. Therefore, one of the causes for higher noise levels in these machines may be a lack of preventive maintenance performed every day and periodically.

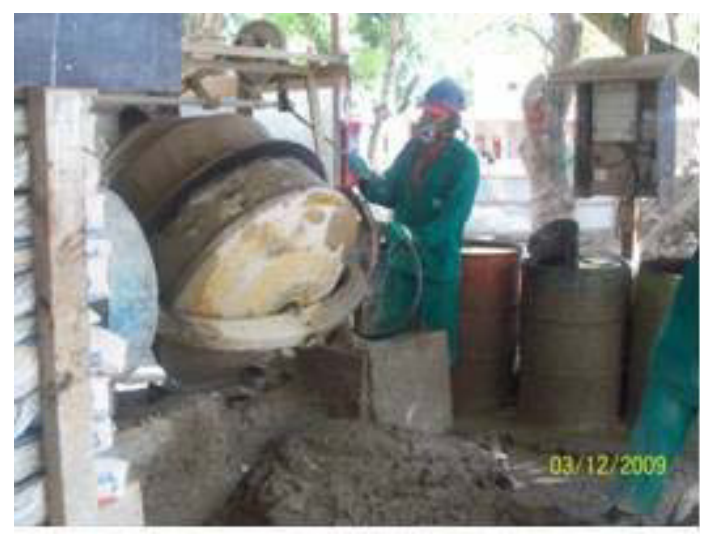

Figure 1: Mixer 1 on site "a"

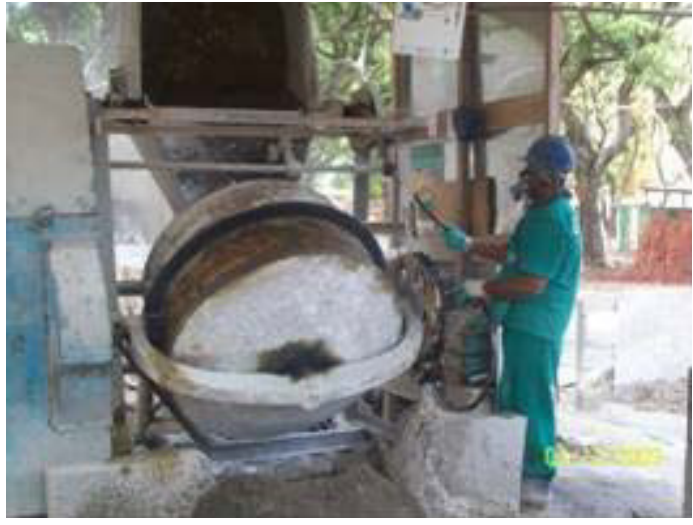

Figure 2: Mixer 2 on site "a"

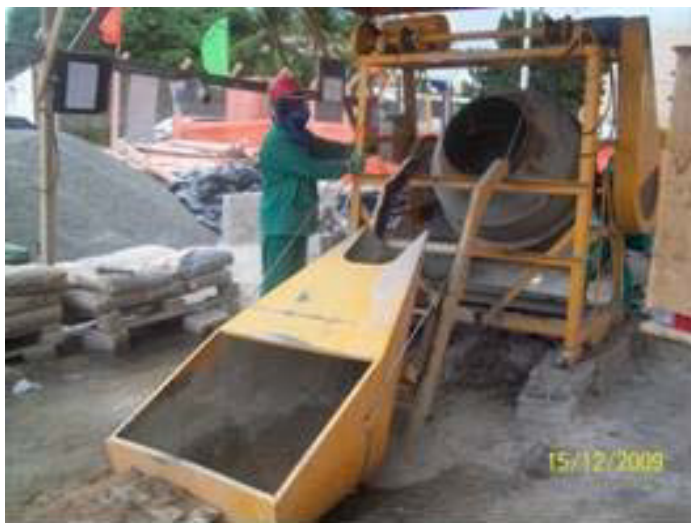

Figure 3: Mixer on site "b" 


\subsubsection{Suggested Measures}

Although six of the seven mixers which were analyzed did not emit levels of noise which contravened regulation NR 15, which is not considered unhealthy, some specific measures can still be taken.

Engineering Control Measures can include: - Opting to install the equipment directly on the ground and ensuring that it is properly flush with the ground - a practice adopted in the sites visited - thus preventing the transmission of vibrations to the structure of the site and, consequently, the generation of noise;

- Protecting the engines of the machines with an insulated box.

Administrative Control Measures that can already be taken are as follows:

- One of the preventive measures suggested is the study of the physical arrangement of the construction site and, more specifically, the positioning of equipment at the beginning of the construction and periodically thereafter. This procedure is intended to limit the number of workers exposed to noise or at least reduce the amount of exposure;

- Developing a preventive maintenance program with daily and periodic revisions, making the necessary repairs, replacing worn or damaged parts, keeping the moving parts clean and lubricated, such as the mixer's transmission box and its nuts and bolts. These measures should be adopted as poorly maintained machines generally produce more intense noise than new or well- maintained machines

\subsection{CircularBench Saw}

\subsubsection{Measurement}

The measurement of circular saws was undertaken in those sites which had the equipment functioning at the time of the field research.

The results of noise and level of exposure found for the circular bench saw, on sites "a" and "c", are presented in Table 2. From the analysis of the results, and using the criterion of $01 \mathrm{NHO}$ which is a more rigorous measurement, it was concluded that the carpenter's exposure to noise on site "a", presents a daily dosage above $100 \%$ and a level of exposure above $85 \mathrm{~dB}$ (a), which requires the immediate adoption of corrective measures. However, in this case the level of noise cannot be characterized as unhealthy since the exposure level of $79 \mathrm{~dB}(\mathrm{~A})$ and daily dose of $44 \%$ are within NR 15 . With regards to the operator of the circular saw on site "c", he is subject to acceptable noise levels. That is to say, below $50 \%$, and a Level of Exposure of $82 \mathrm{~dB}$. In this case, the action to be taken would be to recommend maintaining the existing conditions.

The risk of the circular saws evaluated were classified as light to medium risks.

\subsubsection{Causes of noise}

Circular bench saws are possible causes of noise, with noise emitted from the electric motor, the saw blades, and the vibration of the material being processed. In addition, the noise is characterized by high frequencies that vary with the diameter, speed and equilibrium of the disc, the size and profile of the teeth and the material being cut. When in operation, the saw piece creates high frequencies of sound and these frequencies of sound are more intense when the saw is running on "empty".

\subsubsection{Suggested Measures}

Some suggestions for Engineering Control Measures are presented below:

- Set the hard axis of the saw bench firmly;

- Use a disk of adequate size for each task performed. It is worth noting that large diameter discs produce increased vibration and noise. Therefore, the

Table 2

Measurement of the noise level of circular bench saw

\begin{tabular}{|l|l|c|c|c|c|}
\hline \multicolumn{1}{|c|}{ Equipamento } & Norma & $\begin{array}{c}\text { Dose } \\
(\%)\end{array}$ & $\begin{array}{c}\text { Nivel de Pressáo } \\
\text { Sonor a } \\
\text { Equivalente dB (A) }\end{array}$ & $\begin{array}{c}\text { Consider ação } \\
\text { Técnica }\end{array}$ & $\begin{array}{c}\text { Classificação do } \\
\text { risco }\end{array}$ \\
\hline $\begin{array}{l}\text { Serra Circular } \\
\text { deBancada da } \\
\text { Obra "a" }\end{array}$ & NR -15 & 44 & 79,0 & Aceitável & Desconforto \\
\cline { 2 - 6 } & NHO-01 & 139 & 86,4 & $\begin{array}{c}\text { Acima do limite } \\
\text { de exposição }\end{array}$ & Risco médio \\
\hline $\begin{array}{l}\text { Serra Circular } \\
\text { deBancada da } \\
\text { Obra "c" }\end{array}$ & NR -15 & 15,9 & 71,7 & Aceitável & Desconforto \\
\cline { 2 - 6 } & NHO-01 & 28,2 & 79,5 & Aceitável & Desconforto \\
\hline
\end{tabular}


development of blades with carbide teeth (tipped) allows for a choice of discs with relatively smaller diameters, reducing costs, increasing durability and reducing noise from vibration. In addition, damaged discs must be replaced, periodic sharpening of the saw parts must be performed and "empty" sawing must be prevented for long periods of time;

- Couple to the saw a hard disc backed by a rubber disk to increase both the mass and reduce the impact of the blade, so as to reduce the noise caused by the resonance of the machinery (saw, material or table) in operation.

Administrative Control Measures that may be adopted are as follows:

- Plan the physical layout of the construction site properly, positioning, for example, the circular saw in such a manner so as to limit the number of workers exposed to noise or decrease the amount of exposure;

- The use of protective hearing devices for even short exposure is recommended, given the high noise levels generated at high frequency.

\section{Discussion}

The results show that machinery and equipment used in construction often generate noise levels above the established tolerance levels. The regulation NHO 01, FUNDACENTRO, shows higher accuracy when compared to the standard NR 15, of the Ministry of Labor and Employment. As such, measurements made on the basis of NHO 01 parameters were considered when proposing control measures. However, it is noteworthy that only in those cases where noise exposure exceeds the limit, according to criteria of the NR 15 regulation, characterized are conditions characterized as unsanitary.

The identification of the main generating sources, verification of the likely causes of generation of noise and suggested control measures can be adopted as the first actions to conserve the hearing health of workers. However, it is believed that the risk assessment of physical noise, and the adoption of the practice of prevention must be carried out using management techniques

\section{Conclusions}

Considering the constant noise in the everyday lives of individuals and in order to contribute to the management of health and safety in the organizational field, so as to improve conditions in the work environment of construction companies, this survey has had the general objective of identifying and assessing the risk of physical noise present in the activities of construction sites.

As a result of this study, we observed that the machinery and equipment used frequently on construction sites emit noise levels which expose workers to hazardous which can affect their hearing. Therefore, the need to adopt measures for the prevention and control of the physical risk of noise at construction sites has been made evident However, simply measuring the level of exposure to noise of some operators of machinery and equipment used in construction sites, does not show the full extent of the compromises to health that workers make during the performance of their duties. Therefore, audiometric monitoring for all employees exposed to noise should be undertaken. In addition, planning is necessary in order to adopt the proposed control measures and the commitment of all involved so as to ensure their effectiveness. Finally, there is no point evaluating the physical agent of noise, conduct and follow up audiometric tests periodically and propose administrative and engineering controls, if the employee does not have sufficient knowledge about the risk to which he is exposed, including the implications for their health and the benefits of adopting preventive measures.

\section{References}

[1] Barbosa Filho, Antonio Nunes. Segurança do trabalho e gestão ambiental. $2^{\mathrm{a}}$ ed. São Paulo: Atlas, 2009.

[2] Brasil. Ministério do Trabalho e Emprego. Normas Regulamentadoras de Segurança e Medicina do Trabalho. NR 9 Programa de Prevenção de Riscos Ambientais. Disponível em: www.mte.com.br. Acesso em 10 ago. 2009.

[3] Maia, Paulo Alves. Estimativa de exposições não contínuas a ruído: Desenvolvimento de um método e validação na Construção Civil. 2001. 201f. Tese (Doutorado em Engenharia Civil) - Universidade Estadual de Campinas, Campinas, 2001.

[4] Saliba, Tuffi Messias. Curso básico de segurança e higiene ocupacional. 2 ed. São Paulo: LTr, 2008.

[5] Gabas, Gláucia C. Programa de Conservação Auditiva. Guia Prático 3M. 2004. 71f. Disponível em:http://solutions.3m.com.br/wps/portal/3M/pt_BR/SaudeOc upacional/Home/Profissionais-Seg/PCA/. Acesso em: 05 mai. 2009.

[6] Brasil. Ministério do Trabalho e Emprego. Normas Regulamentadoras de Segurança e Medicina do Trabalho. NR 15 Atividades e Operações Insalubres. Disponível em: www.mte.com.br. Acesso em 10 ago. 2009. 
[7] Fundacentro, São Paulo. Norma de Higiene Ocupacional -

NHO/O1: Avaliação da exposição ocupacional ao ruído. São

Paulo, 2001. $40 \mathrm{p}$ 